Article

\title{
Critical Analysis of a World Heritage Site in Terms of Conservation and Tourism Promotion: The Case of "Ibiza, Biodiversity and Culture" (Ibiza, Spain)
}

\author{
José Ramón-Cardona ${ }^{1}$, David Daniel Peña-Miranda ${ }^{2, *(\mathbb{D})}$ and María Dolores Sánchez-Fernández ${ }^{3}$ (D) \\ 1 Ibiza Island Council University College of Tourism, University of the Balearic Islands, 07800 Ibiza, Spain; \\ jose.ramon@uib.es \\ 2 Faculty of Business and Economic Sciences, Universidad del Magdalena, Carrera 32 No. 22-08, \\ Santa Marta 470004, Colombia \\ 3 Department of Business, University of A Coruña, 15071 A Coruña, Spain; maria.sanchezf@udc.es \\ * Correspondence: ddpena@unimagdalena.edu.co; Tel.: +57-301-251-6006
}

check for

updates

Citation: Ramón-Cardona, J.; Peña-Miranda, D.D.; SánchezFernández, M.D. Critical Analysis of a World Heritage Site in Terms of Conservation and Tourism Promotion: The Case of "Ibiza, Biodiversity and Culture" (Ibiza, Spain). Sustainability 2021, 13, 13250. https://doi.org/10.3390/su132313250

Academic Editor: Jan van der Borg

Received: 24 October 2021

Accepted: 25 November 2021

Published: 30 November 2021

Publisher's Note: MDPI stays neutral with regard to jurisdictional claims in published maps and institutional affiliations.

Copyright: (c) 2021 by the authors. Licensee MDPI, Basel, Switzerland. This article is an open access article distributed under the terms and conditions of the Creative Commons Attribution (CC BY) license (https:// creativecommons.org/licenses/by/ $4.0 /)$.

\begin{abstract}
United Nations Educational, Scientific and Cultural Organization (UNESCO) World Heritage Sites (WHS) have great prestige. Each year, candidatures are presented by advocates seeking to raise awareness of the importance of certain cultural and natural sites, to achieve better protection and to make them known, which can promote tourism to benefit the surrounding regions. One of these cases is Ibiza, which, after a first rejection in 1986, obtained the inscription of "Ibiza, Biodiversity and Culture" in 1999. This WHS is made up of various cultural and natural elements of the island, although the best known is the fortified Upper Town of Ibiza (Dalt Vila). Since then, important restoration and musealization actions have been carried out in the old town, and some tourism promotion events have been held, but there have been failures in its conversion into a tourist product: Both residents and tourists see this as complementary to the traditional offer (sun and beach tourism); confusion has been generated in communication, focusing on the old town and forgetting the other elements; tourist visits to the registered elements have not taken off and are concentrated in the summer months (the traditional high season); some decisions have been politicized, among other problems. Finally, different lines of tourism development are proposed.
\end{abstract}

Keywords: World Heritage; Ibiza; management; tourism; conservation

\section{Introduction}

Ibiza is an island located in the Western Mediterranean with a surface area of $572 \mathrm{~km}^{2}$ and 151,800 inhabitants, characterized by its strong economic dependence on tourism. It received three million tourists in 2019, mostly concentrated in the months of June to September [1]. The city of Ibiza has 51,100 inhabitants. Of them, 2150 live in Dalt Vila, Sa Penya and La Marina, and 1120 live in the urban expansion of Vara de Rey. The city has been treated from archaeological [2,3], architectural [4-6], historical [7,8], sociological [9] and military [10] points of view, but hardly from a tourism point of view.

The tourism that the city receives, as in the rest of the island, is mainly for sun and beach. the prestige of its nightlife and the presence of the rich and famous are attractions. For some decades now, attempts have been made to allow other types of tourism to seasonally diversify, but thus far, no appreciable effects have been achieved. One of the aims has been generating cultural tourism, based on the fortified Upper Town, rural churches, folklore and traditional culture [11-15], but the complexity of managing two tourism sectors with different needs-even though closely linked to each other, such as heritage protection and tourism development [16,17] — has not allowed cultural tourism to pass the stage of planning and minor success.

The declaration of the fortified Upper Town of Ibiza as a World Heritage Site (WHS) by the United Nations Educational, Scientific and Cultural Organization (UNESCO) sought 
to promote the international relevance of the inscribed site and favor alternative tourism, especially heritage tourism, as it is a prestigious distinction with the ability to influence the decisions of travelers [18-30]. After a first attempt, the candidacy was reinforced with natural (the oceanic Posidonia meadows of Es Freus) and archaeological sites (Sa Caleta and Puig des Molins), although they are relegated in the promotion. Finally, in 1999, the inscription of "Ibiza, Biodiversity and Culture" was approved as a mixed site (cultural and natural) on the World Heritage List (WHL).

The research question was: does Ibiza really have the necessary elements to develop this type of tourism? The main elements needed are residents' support and correctly highlighting the importance of WHS. Dividing the research question into two: Do residents support the development of WHS-based tourism? Have the actions to highlight the importance of WHS been implemented correctly, or is there room for improvement? To answer these two questions, analysis of the residents' attitudes toward the type of tourism that allows the WHS to be promoted (Section 5) was conducted, and critical analysis of the actions taken in the WHS was performed (Section 6). We reached the conclusion that residents' attitudes are favorable, and in relation to the actions taken, progress has been made, but many improvements are still possible (Section 7). Before these sections, the WHS declaration process (Section 2), Ibiza's candidacy (Section 3) and the methodology used (Section 4) are described. This study has similarities to others carried out in other sites inscribed on the WHL [20,23,31-40], but in the case of Ibiza, studies with enough depth are lacking-only some approximations exist [14,41].

This paper is divided into various sections. After this, the Introduction, there are two sections dedicated to the candidacy (how the WHS procedure works and the specific case of Ibiza's candidacy), a section dedicated to the methodology, two sections dedicated to the results (residents' attitudes and critical analysis of the actions taken) and a section on conclusions.

\section{The Recognition of World Heritage Sites}

The inscription of cultural or natural sites on the WHL is granted by UNESCO to specific places on the planet that have been proposed and accepted as elements of exceptional universal value. The List is managed by the World Heritage Convention, and their objective is to catalog, preserve and publicize the sites contained on this list. The World Heritage Committee (WHC) meets once a year, makes the final decisions on the inclusion or not of sites, monitors the state of conservation of the inscribed sites, allocates financial aid when necessary and manages the WHL in Danger. The WHL was created based on the Convention Concerning the Protection of the World Cultural and Natural Heritage, the text of which was adopted by the General Conference of UNESCO on 16 November 1972 in Paris. The first session of the WHC occurred in 1977 and the first inscriptions on the List in 1978 [42].

The process for the inscription of a site begins when the country inscribes the site on the Tentative List. The potential nominations that are made must be from locations on this list [24]. As of July 2021, the Tentative List contained 1754 sites from 179 different countries. Nomination begins with the inclusion of a site from the Tentative List in a Nomination File. The file must be as complete as possible and must not only have information about the academic relevance of the sites it contains, but must also present their value [43]. Subsequently, the Nomination File and the site are evaluated by the International Union for Conservation of Nature (IUCN), in the case of natural sites, or the International Council on Monuments and Sites (ICOMOS), in the case of cultural sites. The recommendations of these two entities are central to the final decisions that are made by the WHC at its annual sessions.

For inclusion on the WHL, a candidate site must have "outstanding universal value", which is specified in the fulfillment of at least one of the following selection criteria, of which six are cultural criteria and four are natural [42]: To represent a masterpiece of human creative genius (Criterion I); to exhibit an important cultural exchange, over a 
period of time or within a cultural area of the world, on developments in architecture, monumental arts, urban planning or landscape design (Criterion II); to provide a unique or at least exceptional testimony to a cultural tradition or a living or disappeared civilization (Criterion III); to constitute an outstanding example of a type of building, architecture, technology or landscape ensemble that illustrates a significant stage in human history (Criterion IV); to be an exceptional example of traditional human settlement, land or sea use that is representative of a culture (or cultures), or of human interaction with the environment, especially when it has become vulnerable due to the impact(s) of irreversible changes (Criterion V); to be directly or tangibly associated with events or living traditions, with ideas or beliefs or with artistic or literary works of exceptional universal importance (the Committee considers that this criterion should preferably be accompanied by other criteria (Criterion VI); to showcase superlative natural phenomena or areas of exceptional natural beauty and aesthetic importance (Criterion VII); to be one of the representative examples of the great eras in the history of the earth, including testimonies to life, geological processes that create geological forms or significant geomorphic or physiographic elements (Criterion VIII); to display eminent examples of ecological and biological processes in the evolution and development of land, water, coastal and marine ecosystems (Criterion IX); to contain the most representative and important natural habitats for the in situ conservation of biodiversity, including those that contain endangered species of outstanding universal value from the point of view of science and conservation (Criterion $\mathrm{X}$ ).

After the 44th session of the WHC held in Fuzhou (China) in July 2021, a total of 1154 sites, from 167 different countries, were inscribed on the WHL: 897 cultural, 218 natural and 39 mixed. In the distribution by country, there is a large presence of European countries (especially Italy, Germany, France and Spain), but in recent years, there has been a significant increase in registrations from developing countries, such as China, India and Mexico (Figure 1), a fact promoted by UNESCO itself [42].

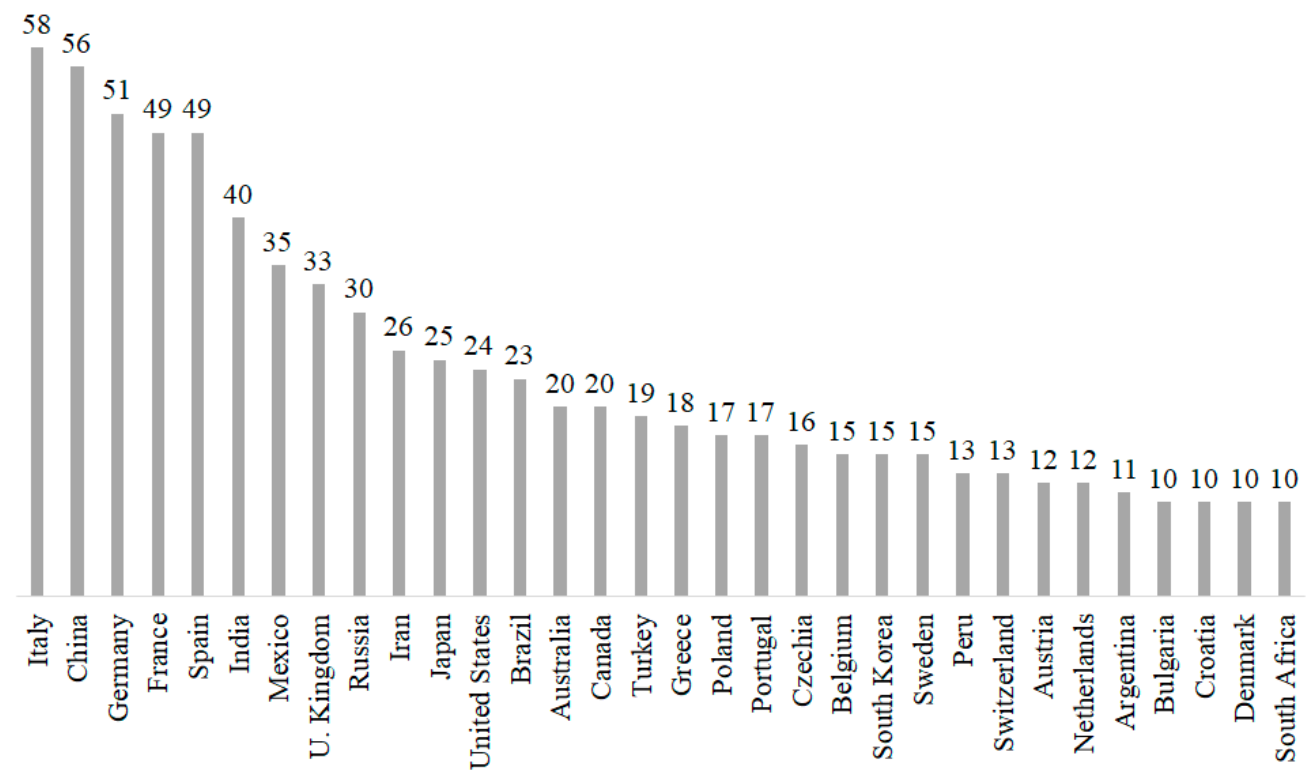

Figure 1. Countries with more than 10 WHS (UNESCO and own elaboration). 
Spain has 43 cultural sites, four natural sites and two mixed sites (i.e., Ibiza and Formentera), totaling 49 sites inscribed on the WHL, in addition to 30 sites on the Tentative List. Spain was not one of the first to inscribe sites on the WHL, since it did not join until 1982 [24] and no inscription was approved until 1984, but in the mid-1980s and during the second half of the 1990s, Spain achieved a large volume of registrations that put it in a leading position (Figure 1).

In the context of Spanish WHSs, the relationships among satisfaction and intention to repeat a visit [44], the environmental risk [45], the carrying capacity [46,47], the motivations to travel $[19,22,48]$, the management entities [49] and the economic impact [50-52] have been analyzed. The degree of knowledge about the places declared WHS has a moderating effect on the causal relationship that determines the behavior of tourists visiting a WHS [53]. Monteiro [54] considered that not only should the tangible value of the inscribed sites be taken into account, but the intangible heritage and the feelings linked to the site ought to be too.

\section{Ibiza on the World Heritage List}

The first attempt to register the fortified Upper Town of Ibiza was promoted by the Dalt Vila Neighbors Association, and the Nomination File was presented in 1986 with the title "Dalt Vila (Ibiza)" and reference 417. Unfortunately, neither the criteria of the Convention Concerning the Protection of the World Cultural and Natural Heritage, nor the guidelines of the World Heritage Convention, were taken into account adequately. In addition, it did not have the necessary support from the island's institutions [43]. Consequently, during the 11th session of the WHC, held in Paris (France) in 1987, the inscription of "Dalt Vila (Ibiza)" on the WHL was rejected on the grounds that [42]:

"Although the Convention recognized the historical value of this site in the Balearic Islands, [we] considered that the material evidence of its multi-millennial past was not enough to justify its inscription on the World Heritage List".

The rejection of the Ibizan candidacy was due to the ICOMOS evaluation report of March 1987 [43]. However, in relation to various rejected candidatures, including that of Ibiza, the WHC indicated that [42]:

"With regard to the last three cultural sites mentioned above, the Convention declared that it would be willing to take into consideration any new nomination prepared in consultation with ICOMOS, if new elements are submitted to justify the inscription of these sites on the World Heritage List".

In the Nomination File presented in June 1998 [43,55,56], the deficiencies of the 1986 file were corrected, following the indications of the World Heritage Convention. The new file did not present a cultural site, but a combination of natural and cultural sites, with great weight placed on archaeological sites and the marine environment of the Ses Salines Natural Reserve. The components of the nomination presented in 1998 were (Figure 2): The fortified Upper Town of Ibiza; the archaeological sites of Sa Caleta and Puig des Molins; the oceanic Posidonia meadows located within the Ses Salines Natural Reserve. 


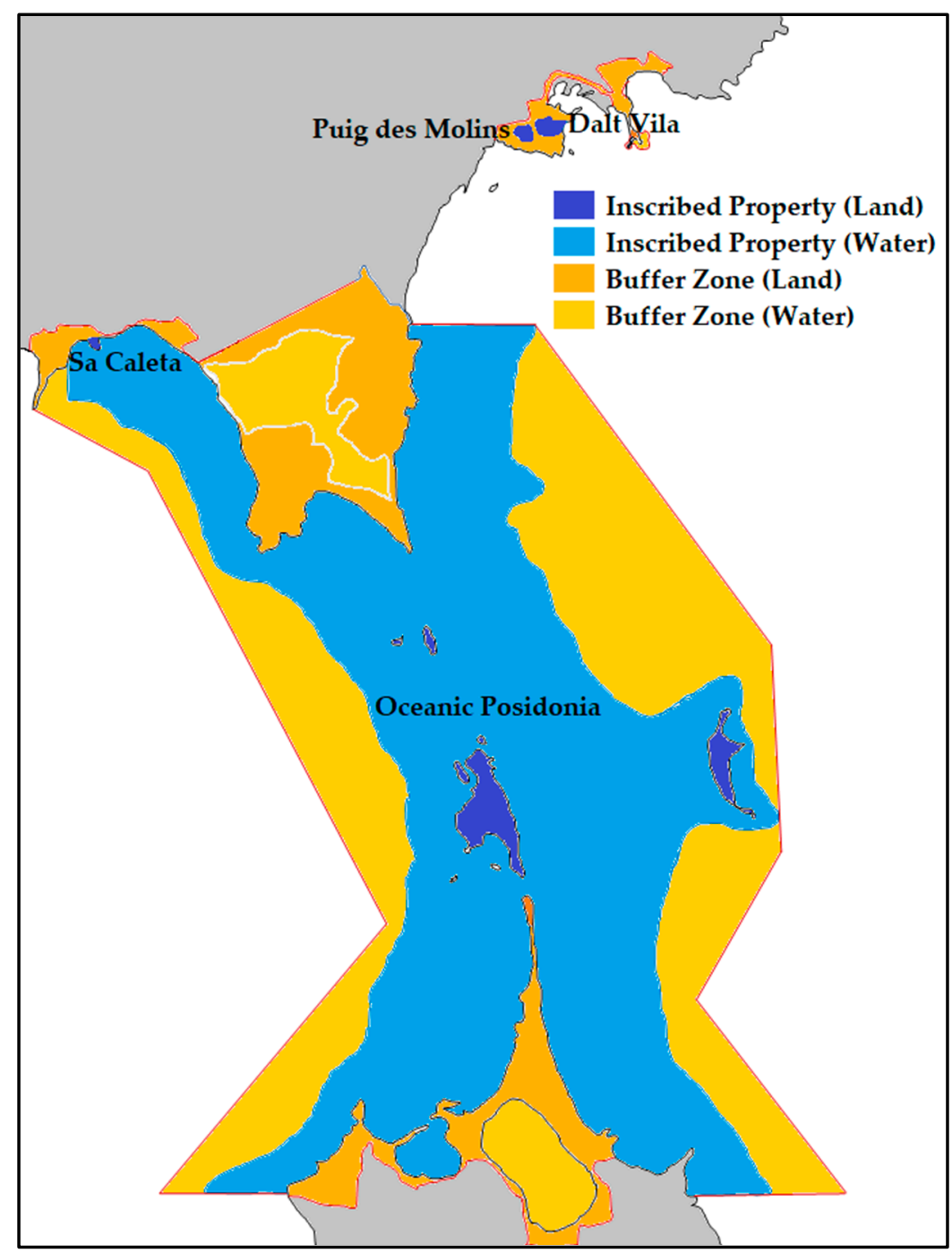

Figure 2. Candidacy of "Ibiza, Biodiversity and Culture" (own elaboration).

\subsection{The Foartified Upper Town of Ibiza/Eivissa}

The original urban nucleus was constituted in what is called Puig de Vila, placing the necropolis in Puig des Molins. The founding of the Phoenician colony according to classical historiography dates back to $654 \mathrm{BC}$, and the settlement has been archaeologically dated to the beginning of the 6th century BC [57]. Throughout the Punic era, it was a key point in the commercial routes of the city of Carthage. In the 10th century, Medina Yabisah was part of the Al-Andalus territories, and it is a period that is abundantly documented in terms of archaeological and urban records. In 1235, the town and island were incorporated into the Crown of Aragon. During the 16th century, there were frequent attacks that could not be repelled with the medieval walls, and this forced the construction of the Renaissance walls. During the 17th and 18th centuries, there was a strong expansion of the La Marina neighborhood, which came to surpass the fortified Upper Town in population and importance. The neighborhoods of the historic town are divided in two by the walls. Within the walls (Dalt Vila), there are two different urban areas: The urban area of medieval origin (8th-15th centuries), and the Renaissance urban area or Vila Nova (16th century). Outside of the walls are the neighborhoods of Sa Peña (17th century), La Marina (14th-19th centuries) and Vara de Rey (20th century). The fortified Upper Town of Ibiza/Eivissa is made up of seven elements:

- The Renaissance walls. The oldest references to walls around the city of Ibiza go back to Diodorus of Sicily (1st century BC), who copied the work of Timaeus of 
Taormina (3rd-4th centuries BC) and indicated that the city was well built and had walls. However, there are still no archaeological data from ancient times to corroborate this [57]. It is from the period of Muslim dominion (10th to 13th centuries) which documentation and archaeological certainties emerged in abundance about the walled enclosure that the city had. The medieval wall was divided into three enclosures (Vila d'Amunt, Vila d'Enmig and Vila d'Avall or suburb) topped with a castle in the highest area [55,57]. The Renaissance walls of Ibiza were part of a modernization plan promoted by Emperor Carlos I and continued by his son, Felipe II, in order to defend the territories of the Spanish crown against the French crown and the Ottoman Empire. This modernization consisted of the incorporation of the latest developments in Italy [58], especially the use of bastions as a defensive system against artillery attacks [55,57]. Giovanni Battista Calvi da Caravaggio designed the first layout of the Renaissance wall in 1554, following the layout of the medieval walls. The work began in 1555, and in charge was the master builder Antoni Jaume [43,57,58]. Giovan Giacomo Paleazzo El Fratín replaced Giovanni Battista Calvi in 1565 and reformed and expanded the project in 1575. The expansion involved incorporating Puig de Santa Llúcia into the fortified enclosure $[43,57,59]$. This fortification project was a precedent and a reference point for the fortifications made in the American lands under Spanish domain [43]. The opening of air-raid shelters, a tunnel between Es Soto and the town hall square, the installation of water tanks in some bastions and the opening of an access in the bastion of Sant Joan to facilitate road traffic are the only significant alterations that the walls have suffered since its improvements were completed in the 18th century [57].

- Intramural neighborhood (Dalt Vila). This is the upper part of the historic center and is surrounded by the Renaissance walls. Within this neighborhood, there are two clearly differentiated urban sectors: One corresponds to the medieval town, and the other is the expansion of the medieval town under the protection of the Renaissance walls (Vila Nova). In the part of medieval origin, vestiges of the medieval wall are still preserved. In the highest part are the most representative buildings of the civil, military, judicial, economic and ecclesiastical power of the island for centuries: the local government, the Castle and Saint Mary's Cathedral. Next, there are other buildings, such as the Chapel of the Savior or the House of the Curia, and the largest residences in the town. When descending through the medieval town, neighborhoods of more modest status follow one another until reaching the suburbs. The lower part of the medieval town has been invigorated by the opening of shops, restaurants and bars focused on tourism, especially Vila Square, Holy Cross Street and Sun Square. In Vila Nova, there are notable buildings, such as the Dominican Convent and the House of the Society of Jesus [60].

- Sa Penya neighborhood. This neighborhood is located at the eastern end of the historic town, between the wall and the sea, under the bastion of Santa Llúcia and the wall that joins this bastion with the bastion of Sant Joan. It is located between the wall and La Marina neighborhood. On the sea side, it reaches the edge of a cliff. This neighborhood, together with that of La Marina, constituted the extramural suburb from the 16th century to the 19th century. The Sa Penya neighborhood was traditionally a fishermen's neighborhood. At present, the neighborhood is degraded, with marginality problems and with many of the houses being in a state of ruin [61]. The main tourist attraction is Broner House, built by Erwin Broner in 1959 as his personal residence.

- La Marina neighborhood. This is the maritime neighborhood of the historic center and is located between the walls, the Sa Penya neighborhood and the port. It is the lowest neighborhood in the historic complex and is practically at sea level. The original nucleus of this neighborhood began in the 14th century. Until that time, these lands constituted the port area. In its beginnings, it was inhabited by shipyard workers and 
seamen. During the 17 th and 18 th centuries, it was the most populous and prosperous neighborhood in the town, surpassing Dalt Vila [62].

- Vara de Rey Neighborhood. This is the first modern urban extension planned after the demolition of the second stockade, at the end of the 19th century. This neighborhood has emblematic buildings, such as Montesol Hotel, Pereira Theater and Ebusus Society [55], all of them built between the end of the 19th century and the first third of the 20th century. The inhabitants of the oldest parts of the town moved toward this neighborhood in search of more spacious and modern houses. Today, it is taking an increasingly touristy approach, while losing importance among residents in favor of more modern neighborhoods.

- Es Soto. This is an undeveloped area located between the walls and the sea. In it, there are elements of cultural value, such as remains of the Levante mills; tombs as a possible expansion of the Puig des Molins necropolis; remains of PhoenicianPunic ceramics; Canon's Bench; signs of extraction of millstones; an Islamic cemetery; remains of a chapel, a cross and a Stations of the Cross; and Punic cisterns [43]. It is a key area for the image of the fortified Upper Town, and it was not urbanized because it was under military ownership until relatively recent times.

- $\quad$ The cultural landscape of Ses Feixes. This term refers to the portions of arable land resulting from the drainage of marshy lands located near the port of Ibiza and the nearby bay of Talamanca, surrounded by ditches that facilitate controlling the drainage of the land [63]. In the past, Ses Feixes reached an area of $600,000 \mathrm{~m}^{2}$ spread over 145 plots $[64,65]$. The oldest of these plots was dated to the end of the 17 th century, since until then, the areas located on the western shore of the port and Talamanca beach were marshy lands [63]. In the Nomination File, only Prat de Ses Monges was presented, since Prat de Vila is irrecoverable. El Prat de Ses Monges occupied $307,000 \mathrm{~m}^{2}$, divided into 61 plots, with a network of ditches of 14,500 m [64]. At present, Prat de Ses Monges is very deteriorated [65].

\subsection{Archaeological Site of the Punic Necropolis of Puig des Molins}

In Puig des Molins is the necropolis of the town during antiquity. Puig des Molins is located $500 \mathrm{~m}$ from Puig de Vila, the original nucleus of the town, and owes its name to the presence of mills on its top that have been there since the 15th century. In recent centuries, this mountain was dedicated to agriculture in terraces, and olive, almond, carob and fig trees were planted-in many cases in the access wells to ancient tombs. Currently, the agricultural activity has disappeared and a large part of the area is fenced and integrated into the necropolis museum. Three hundred and forty hypogea are visible, although it is estimated that there could be 3000 tombs across the entire area.

\subsection{Archaeological Site of the Sa Caleta Settlement}

This archaeological site corresponds to the remains of a Phoenician settlement located on the Sa Caleta peninsula, next to the cove of the same name, discovered in 1986. It is the main vestige of the most archaic period of Phoenician colonization, since its origin could date back to the 8 th century BC. At the end of the 7th century BC, it reached its maximum degree of extension and architectural density, being abandoned at the beginning of the 6th century BC in a planned and peaceful way. A possible hypothesis for the abandonment of this settlement is that the population moved to the bay, occupying Puig de Vila and founding the town of Ibiza [66].

\subsection{The Oceanic Posidonia Meadows}

Oceanic Posidonia is an endemic Mediterranean phanerogam with characteristics of higher plants (roots, stems, leaves and the ability to produce flowers and fruits with seeds) and a high sensitivity to environmental disturbances. It grows on the sandy seabed, forming extensive and dense meadows inhabited by a great diversity of living beings, of which three endangered species can be highlighted: Loggerhead sea turtle (Caretta caretta), 
Mediterranean monk seal (Monachus monachus) and common bottlenose dolphin (Tursiops truncatus). In addition, over the centuries, the oceanic Posidonia meadows have formed structures, up to 3-4 $\mathrm{m}$ high, that protect the coasts and facilitate the formation and stability of the beaches and coastal dune structures, which in turn have allowed the appearance of juniper forests [56,67]. The inscribed oceanic Posidonia meadows correspond to the Natural Reserve (today, the Natural Park) of Ses Salines [56]. The Ses Salines Natural Park of Ibiza and Formentera is an area protected by Law 17/2001 of December 2019. The Natural Park has an area of 15,396.90 ha (13,610.58 marine and 1786.32 land). The oceanic Posidonia covers up to $70-80 \%$ of the seabed in the Natural Park and has an excellent state of conservation. Its good state of conservation is manifested in the presence of annual flowering, the existence of wide extensions of dense meadows and the presence of meadows at depths of up to 30-40 $\mathrm{m}$ [56].

Within this area is the cultural landscape of Ses Salines. The salt flats of Ibiza are the result of human action on areas that were possibly originally wetlands. It is believed that the exploitation of the salt flats began in Punic times, continuing uninterruptedly to the present day. The salt flats occupy some 400 ha and make up the largest wetland area on the island. Currently, they remain the property of Salinera Española S.A. and produce between 40,000 and 50,000 tons per year [68].

The 23rd session of the WHC, held in Marrakech (Morocco) in 1999, was attended by the delegation of the Ibiza nomination, made up of the municipal team at that time, Xico Tarrés (mayor) and Lurdes Costa (councilor for culture), and his predecessors and those responsible for reactivating the nomination, Enrique Fajarnés (mayor) and Josefa Costa (councilor for culture). On 4 December 1999, the WHC inscribed "Ibiza, Biodiversity and Culture" on the WHL, with the reference 417Rev. The World Heritage Convention's brief description of this WHS is [42]:

"Ibiza offers an excellent example of the interaction between marine and coastal ecosystems. The dense meadows of oceanic Posidonia, an important endemic species found only in the Mediterranean basin, contain and support a diversity of marine life. Ibiza preserves considerable vestiges of its long history. The archaeological sites of Sa Caleta (settlement) and Puig des Molins (necropolis) testify to the important role played by the island in the Mediterranean economy in protohistory, particularly during the Phoenician-Punic period. The fortified Upper Town (Dalt Vila) is an exceptional example of Renaissance military architecture; it had a profound influence on the development of fortifications in the Spanish settlements of the New World".

The Committee justified the inscription based on five criteria [42]:

- $\quad$ Criterion (IX): The evolution of the Ibiza coast is one of the best examples of the influence of oceanic Posidonia on the interaction of coastal and marine ecosystems.

- $\quad$ Criterion $(X)$ : The well-preserved oceanic Posidonia, threatened in most parts of the Mediterranean, contains and supports a great diversity of marine life.

- Criterion (II): Ibiza's intact 16th century fortifications bear unique witness to the military architecture and the engineering and aesthetics of the Renaissance. This Italian-Spanish model was very influential, especially in the construction and fortification of cities in the New World.

- $\quad$ Criterion (III): The Phoenician ruins of Sa Caleta and the Phoenician-Punic cemetery of Puig des Molins are exceptional evidences of urbanization and social life in the Phoenician colonies of the western Mediterranean. It constitutes a unique resource, in terms of volume and importance, the material of the Phoenician and Carthaginian tombs.

- Criterion (IV): The Upper Town (Dalt Vila) is an excellent example of a fortified acropolis that exceptionally preserves, in its walls and in its urban layout, successive impressions of the first Phoenician settlements and of the Arab and Catalan periods through the Renaissance bastions. The long process of construction of the fortifications has not destroyed the previous phases and the urban layout but has incorporated them in the final phase. 
Therefore, the elements proposed for inscription, with a total area of 9020 ha, are [42]: the oceanic Posidonia meadows; the Upper Town (Dalt Vila) of Ibiza and its 16th century walls; the Phoenician-Punic necropolis of Puig des Molins; the Phoenician-Punic archaeological site of Sa Caleta. The assets that make up the protection or buffer area, with a total area of 7568 ha, are [42]: the neighborhoods of Sa Peña, La Marina and Vara de Rey; Es Soto; Ses Feixes (Prat de Ses Monges); Ses Salines (salt flats).

On 28 March 2001, the Ibiza World Heritage Site Consortium was constituted, to which the Ibiza Town Hall, the Insular Council and the Balearic Government contribute in equal parts. The Consortium was created to promote, coordinate and finance the different actions to be carried out at the sites declared WHS. With the Consortium funds, works were financed in Dalt Vila, Sa Penya and La Marina [69].

In 2002, the drafting of the Master Plan for the Renaissance Walls of Ibiza was assigned to an interdisciplinary team with the aim of carrying out an academic and in-depth study of the walls. Based on the information obtained with the Master Plan, the bastion of Sant Pere (Portal Nou), the bastion of Sant Jaume, the powder magazine, the Portal of Ses Taules (the main gate of the walls) and the parapets of the bastions of Sant Pere and Santa Llúcia were restored. The fortified enclosure was also musealized: Placement of information stands throughout Dalt Vila (2003) and replicas of cannons in Santa Llúcia and Sant Jaume (2003); opening of the exhibition spaces of the Madina Yabisa Interpretation Center (2007) and the casemates of Sant Pere (2007) and Sant Jaume (2008). Moreover, Can Botino (from the 17th century) was made the new town hall (2006), and the House of the Curia (from the 13th century) was made the Madina Yabisa Interpretation Center (2007). The Museum of Contemporary Art was expanded (2012), the Sant Ciriac Street Workshop School was remodeled (2006), the Puget Museum was opened in Can Comaseca (2007) and social housing was created (2009). The completion of the castle hotel (Paradores de España hotel chain) is pending. Interventions were also carried out in the Sa Penya and La Marina neighborhoods. Other improvements are the pedestrianization of streets, the hiding of garbage containers, the renewal of signage, the lighting of monuments, the burying of cables and the construction of new sanitation networks [69].

To promote cultural tourism, on 27 September 2002, the mayor of Ibiza signed the municipality's entry into the group World Heritage Cities of Spain [69]. The group was created in 1993 and is currently made up of 15 cities with elements from 14 sites inscribed on the WHL: Cordoba (Historic Centre of Cordoba, 1984), Ávila (Old Town of Ávila with its Extra-Muros Churches, 1985), Santiago de Compostela (Santiago de Compostela-Old Town, 1985), Segovia (Old Town of Segovia and its Aqueduct, 1985), Caceres (Old Town of Caceres, 1986), Toledo (Historic City of Toledo, 1986), Salamanca (Old City of Salamanca, 1988), Merida (Archaeological Ensemble of Merida, 1993), Cuenca (Historic Walled Town of Cuenca, 1996), Alcala de Henares (University and Historic Precinct of Alcala de Henares, 1998), Ibiza (Ibiza, Biodiversity and Culture, 1999), San Cristobal de La Laguna (San Cristobal de La Laguna, 1999), Tarragona (Archaeological Ensemble of Tarraco, 2000) and Baeza and Ubeda (Renaissance Monumental Ensembles of Ubeda and Baeza, 2003). The group's objectives are to act jointly in the defense of the historical and cultural heritage of the cities that compose it, defend common interests, study solutions to similar problems and promote cultural tourism of historical and artistic quality through its cities [70].

\section{Methodology}

In the article by Mondéjar et al. [71], of 11 cities with WHS, Ibiza was in 8th place in a ranking that evaluated the tourism potential. If we take into account that, thanks to sun and beach tourism, Ibiza has advanced infrastructure (hotels, apartments, restaurants, airport, port, etc.), far superior to that of other cities in the study, these data indicate that something does not work properly in the area. The objective of this paper was to try to determine what may be happening for this situation to occur. For this, various tools were used and analysis was carried out, divided into two parts: In the first part, the level of support of the residents for the tourism that would support a WHS was analyzed, that is, 
tourism based on nature and cultural heritage; in the second part, a critical analysis of the current situation regarding the management and promotion of WHS was carried out.

For the first part, an exploratory analysis was carried out using a Structural Equation Model (SEM), proposing an SEM similar to previous studies, e.g., [72], specifically Partial Least Squares (PLS) regression. PLS-SEM is an analysis technique that is more advanced than multiple linear regression, as it analyzes several regressions simultaneously. For this, the SmartPLS software [73] and the path weighting system were used, by providing higher $R$-squared values for the latent variables [74]. This analysis was performed on a database from a convenience sample of 418 Ibizan residents (the maximum margin of error given a $95 \%$ confidence level was $4.89 \%$ ). To contact the people in the sample, streets of each town on the island were selected. We distributed questionnaires among residents who worked on or frequented those streets. To ensure the level of representativeness of the sample, the demographic variables of the collected questionnaires were controlled in order to reduce biases in the sample profile. The questionnaire contained items with five-point Likert scales adapted from previous studies [72,75-77] and questions about sociodemographic factors (Table 1). The Likert scales were as follows: $1=$ total disagreement, $3=$ indifferent, and $5=$ total agreement, for the items on the impact on perception and residents' attitudes; and $1=$ totally unacceptable, $3=$ indifferent, and $5=$ totally acceptable for a tourism offering.

Table 1. Demographic profile of the sample.

\begin{tabular}{|c|c|c|}
\hline Demographic Variable & Frequency & $\%$ \\
\hline \multicolumn{3}{|l|}{ Gender: } \\
\hline Male & 151 & $36.12 \%$ \\
\hline Female & 266 & $63.64 \%$ \\
\hline They do not answer & 1 & $0.24 \%$ \\
\hline \multicolumn{3}{|l|}{ Age: } \\
\hline Less than 25 years & 55 & $13.16 \%$ \\
\hline 25 to 34 years & 102 & $24.40 \%$ \\
\hline 35 to 44 years & 98 & $23.44 \%$ \\
\hline 45 to 54 years & 88 & $21.05 \%$ \\
\hline 55 or more years & 48 & $11.48 \%$ \\
\hline They do not answer & 27 & $6.46 \%$ \\
\hline \multicolumn{3}{|l|}{ Level of Studies: } \\
\hline Primary studies & 92 & $22.01 \%$ \\
\hline Secondary studies & 175 & $41.87 \%$ \\
\hline University studies & 148 & $35.41 \%$ \\
\hline They do not answer & 3 & $0.72 \%$ \\
\hline \multicolumn{3}{|l|}{ Work in the tourism sector: } \\
\hline Yes & 256 & $61.24 \%$ \\
\hline No & 157 & $37.56 \%$ \\
\hline They do not answer & 5 & $1.20 \%$ \\
\hline \multicolumn{3}{|l|}{ Annual net family income: } \\
\hline Less than $€ 15,000$ & 46 & $11.00 \%$ \\
\hline From $€ 15,001$ to $€ 30,000$ & 150 & $35.89 \%$ \\
\hline From $€ 30,001$ to $€ 45,000$ & 96 & $22.97 \%$ \\
\hline From $€ 45,001$ to $€ 60,000$ & 37 & $8.85 \%$ \\
\hline From $€ 60,001$ to $€ 75,000$ & 12 & $2.87 \%$ \\
\hline More than $€ 75,000$ & 10 & $2.39 \%$ \\
\hline They do not answer & 67 & $16.03 \%$ \\
\hline
\end{tabular}

For the second part, a case study was carried out by consulting various secondary information sources (bibliography, web pages and local press), including a visit to the WHS and consultation with heritage technicians from local institutions. Based on this information, a critical analysis of the measures undertaken, and the results obtained on converting the WHS into a tourism offering were prepared for reporting. 


\section{Analysis of Residents' Attitudes}

For sustainable tourism development, it is essential to take into account residents' attitudes [78], as without their support, it is almost impossible to start a tourism development project, including those linked to WHS [79]. Of the various types of impacts generated by tourism [80-83], the economic benefits were the most prominent and wanted by the residents $[72,75,77,82-87]$. In practice, residents value tourism based on a comparison between economic benefits and sociocultural and environmental impacts [88,89]. Therefore, the economic impact is of great relevance $[72,77,85-87,90]$, having a positive effect on residents' attitudes [85-87,91,92]. Sociocultural and environmental impacts have unclear effects. In relation to the sociocultural impact, a transformation of the local society and culture occurs, being seen as positive $[77,83,90]$ or negative $[82,83,93,94]$ depending on whether residents have a dynamic or a static image of their culture [95]. In relation to the environment, concerns about the natural environment are common [85,94,96,97], and these concerns have a negative effect on residents' attitudes $[72,85,94]$. Therefore, the following hypotheses were developed:

Hypothesis 1 (H1). The economic benefits have a positive effect on the residents' attitudes.

Hypothesis 2 (H2). The cultural benefits have a positive effect on the residents' attitudes.

Hypothesis 3 (H3). The natural costs have a negative effect on the residents' attitudes.

Residents' attitudes may not be the same toward different tourism offerings. A positive attitude does not imply equal acceptance of all types of tourism. Residents' attitudes affect the degree of acceptance of traditional tourism $[82,83,86,87]$ and tourism that seeks to promote WHS [86]. It is also proposed that traditional tourism affects the degree of acceptance of cultural and nature tourism, as it is seen as a complementary offer that seeks to diversify the traditional one. Therefore, the following hypotheses were developed:

Hypothesis 4 (H4). The residents' attitudes have a positive effect on the acceptance of traditional offer.

Hypothesis $\mathbf{5}$ (H5). The residents' attitudes have a positive effect on the acceptance of World Heritage offer.

Hypothesis 6 (H6). The acceptance of traditional offer has a positive effect on the acceptance of World Heritage offer.

Based on all of the above, an SEM was proposed with the six hypotheses raised (Figure 3).

When proceeding to the analysis of the SEM, the measurement model had to first be analyzed to perform a series of checks that ensured the quality of the structural model: reliability, convergent validity and discriminant validity. To ensure individual reliability, the items must have loads greater than 0.707 [98], and this condition was fulfilled by all of the items used. The construct reliability measures the consistency of the indicators, and the two most common tests are Cronbach's alpha [99] and composite reliability [100], both tests being reasonably good in this case (Table 2). Convergent validity [101] means that a set of items represents a single underlying construct; this can be analyzed through its onedimensionality [74], but it is usually valued through an Average Variance Extracted (AVE) greater than 0.5 (Table 2), as indicated in the literature [102]. Discriminant validity [101] means that each construct must be different from the rest, being analyzed through cross loadings and comparing the correlations with the square root of AVE [103], the latter appearing in Table 3. After the analysis of the measurement model, the scales used in the analysis of the structural model were those shown in Table 4. 


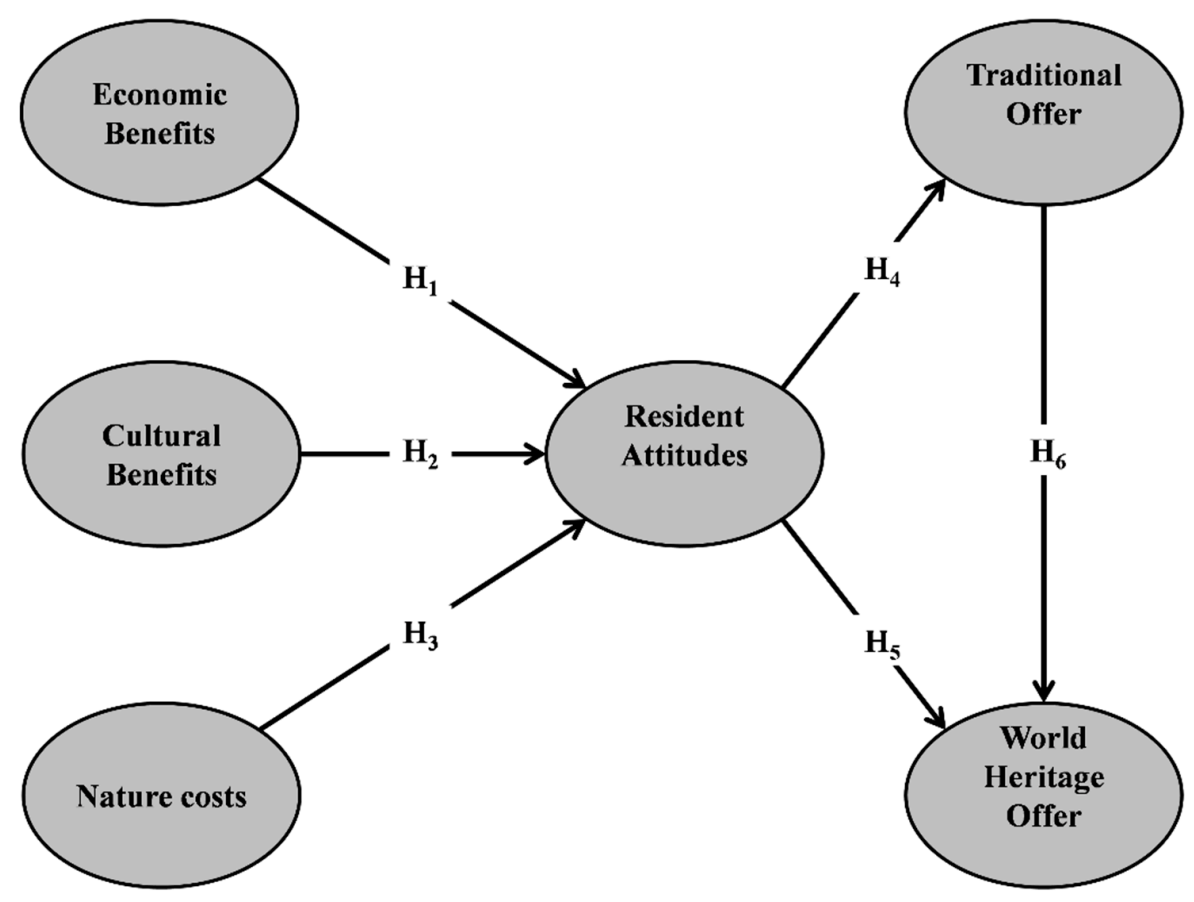

Figure 3. Proposed SEM (own elaboration).

Table 2. Reliability and convergent validity of the constructs.

\begin{tabular}{ccccc}
\hline & AVE & Composite Reliability & R Square & Cronbach's Alpha \\
\hline Cultural Benefits & 0.598 & 0.817 & & 0.664 \\
Economic Benefits & 0.643 & 0.844 & & 0.723 \\
Nature costs & 0.618 & 0.828 & & 0.691 \\
Resident Attitudes & 0.590 & 0.852 & 0.339 & 0.768 \\
Traditional Offer & 0.599 & 0.818 & 0.118 & 0.667 \\
World Heritage Offer & 0.856 & 0.923 & 0.257 & 0.833 \\
\hline
\end{tabular}

Table 3. Correlations and square roots of AVE.

\begin{tabular}{ccccccc}
\hline & $\mathbf{( 1 )}$ & $\mathbf{( 2 )}$ & $\mathbf{( 3 )}$ & $\mathbf{( 4 )}$ & (5) & (6) \\
\hline Cultural Benefits (1) & 1.000 & & & & & \\
Economic Benefits (2) & 0.321 & 1.000 & & & & \\
Nature costs (3) & -0.371 & -0.105 & 1.000 & & & \\
Resident Attitudes (4) & 0.435 & 0.479 & -0.292 & 1.000 & & \\
Traditional Offer (5) & 0.202 & 0.232 & -0.109 & 0.343 & 1.000 & \\
World Heritage Offer (6) & 0.136 & 0.154 & 0.032 & 0.168 & 0.507 & 1.000 \\
\hline Square Root of AVE & 0.773 & 0.802 & 0.786 & 0.768 & 0.774 & 0.925 \\
\hline
\end{tabular}

To test whether the path coefficients of the structural model are significant, a nonparametric bootstrap procedure was applied [104] with 5000 subsamples created randomly from the original sample by substitution with a replacement. The estimates of the parameters generated with the bootstrap procedure were used to determine the standard errors [105], and the results of the significance analysis are detailed in Table 5 and Figure 4.

When reviewing the results of the SEM analysis (Table 5), it can be seen that the three types of impacts ( $\mathrm{H} 1, \mathrm{H} 2$ and $\mathrm{H} 3)$ traditionally posed $[80,81]$ have an effect and were as expected $[72,75,77,82-87,90,94,96,97]$. It should be noted that economic benefits are those that have the most important effect on residents' attitudes (H1), as indicated by previous studies $[72,77,78,84-87,90,92]$.

Residents' attitudes have a direct and important effect on the degree of acceptance of traditional tourism $(\mathrm{H} 4)$, as indicated by previous studies $[82,83,86,87]$, but not on the 
degree of acceptance of tourism that enables the Ibiza WHS to be promoted (H5). There is a positive and strong relationship between the acceptance of traditional tourism and the degree of acceptance of tourism linked to the WHS (H6). The analyses of hypotheses 4, 5 and 6 indicated that tourism related to the WHS is not an alternative to traditional sun and beach tourism, but rather a complement that enriches it, always according to residents. Tourism linked to the WHS cannot replace the traditional tourism, but it can complete it and expand its results and benefits. In fact, this complementarity is already clear, with visits to the WHS being a common option for the days less suitable for sun and beach tourism.

The WHS of Ibiza is mixed and is made up of elements that allow promoting two types of tourism with the great acceptance among the residents (Table 4): cultural tourism (4.42 out of 5) and nature tourism (4.48 out of 5). Therefore, the residents have a high degree of acceptance of tourism linked to the WHS, but link it to traditional sun and beach tourism (Table 5). With this, it can be seen that the support of residents, essential for sustainable tourism development [78], is present.

Table 4. Arithmetic means, standard deviations and loadings of the conserved items.

\begin{tabular}{|c|c|c|c|}
\hline & Arithmetic Mean & Standard Deviation & Loading \\
\hline \multicolumn{4}{|l|}{ Economic Benefits: } \\
\hline Thanks to tourism, job opportunities are higher & 4.495 & 0.657 & 0.819 \\
\hline Tourism stimulates investment on the island & 4.278 & 0.767 & 0.792 \\
\hline Tourism increases business opportunities & 4.325 & 0.748 & 0.795 \\
\hline \multicolumn{4}{|l|}{ Cultural Benefits: } \\
\hline Tourism has increased cultural and recreational activities & 3.323 & 1.069 & 0.794 \\
\hline Tourism has generated a positive cultural exchange & 3.730 & 0.979 & 0.816 \\
\hline Tourism has helped to conserve the cultural heritage & 3.268 & 1.115 & 0.707 \\
\hline \multicolumn{4}{|l|}{ Nature Costs: } \\
\hline Tourism has contributed to the environmental degradation & 3.713 & 1.161 & 0.882 \\
\hline Tourism has caused the saturation of certain natural spaces & 3.842 & 1.076 & 0.757 \\
\hline Tourism favors the conservation of natural resources $\left(^{*}\right)$ & 2.816 & 1.075 & 0.710 \\
\hline \multicolumn{4}{|l|}{ Residents' Attitudes: } \\
\hline I am proud that so many tourists want to visit Ibiza & 4.177 & 0.929 & 0.758 \\
\hline The positive effects outweigh the negative ones & 3.660 & 1.021 & 0.783 \\
\hline Thanks to tourism, we have a higher quality of life & 3.799 & 0.992 & 0.763 \\
\hline I believe that tourism generates benefits for everyone & 4.146 & 0.915 & 0.768 \\
\hline \multicolumn{4}{|l|}{ Traditional Offer: } \\
\hline Vacation homes (rent) & 4.225 & 0.857 & 0.756 \\
\hline Second residence tourism (owners) & 4.033 & 0.963 & 0.775 \\
\hline Family sun and beach tourism & 4.443 & 0.808 & 0.790 \\
\hline \multicolumn{4}{|l|}{ World Heritage Offer: } \\
\hline Nature-based tourism & 4.483 & 0.833 & 0.916 \\
\hline Culture-based tourism & 4.421 & 0.853 & 0.935 \\
\hline
\end{tabular}

Note: $\left({ }^{*}\right)$ This variable has been transformed for the SEM analysis, adopting an inverse sign.

Table 5. Path coefficients, standard error and $p$ values.

\begin{tabular}{|c|c|c|c|c|}
\hline & Path Coefficients & Standard Error & T Statistic & $p$ Value \\
\hline Economic Benefits $\rightarrow$ Residents' Attitudes (H1) & $0.381 * * *$ & 0.092 & 4.162 & 0.000 \\
\hline Cultural Benefits $\rightarrow$ Residents' Attitudes (H2) & $0.254 * *$ & 0.100 & 2.551 & 0.011 \\
\hline Nature costs $\rightarrow$ Residents' Attitudes (H3) & $-0.158 *$ & 0.086 & 1.831 & 0.067 \\
\hline Residents' Attitudes $\rightarrow$ Traditional Offer (H4) & $0.343^{* * *}$ & 0.099 & 3.462 & 0.001 \\
\hline Residents' Attitudes $\rightarrow$ World Heritage Offer (H5) & $-0.007^{\mathrm{ns}}$ & 0.097 & 0.073 & 0.942 \\
\hline Traditional Offer $\rightarrow$ World Heritage Offer (H6) & $0.509 * * *$ & 0.096 & 5.326 & 0.000 \\
\hline
\end{tabular}

* Significant at $0.1 ;{ }^{* *}$ significant at $0.01 ;{ }^{* * *}$ significant at $0.001 ;{ }^{\text {ns }}$ not significant. 


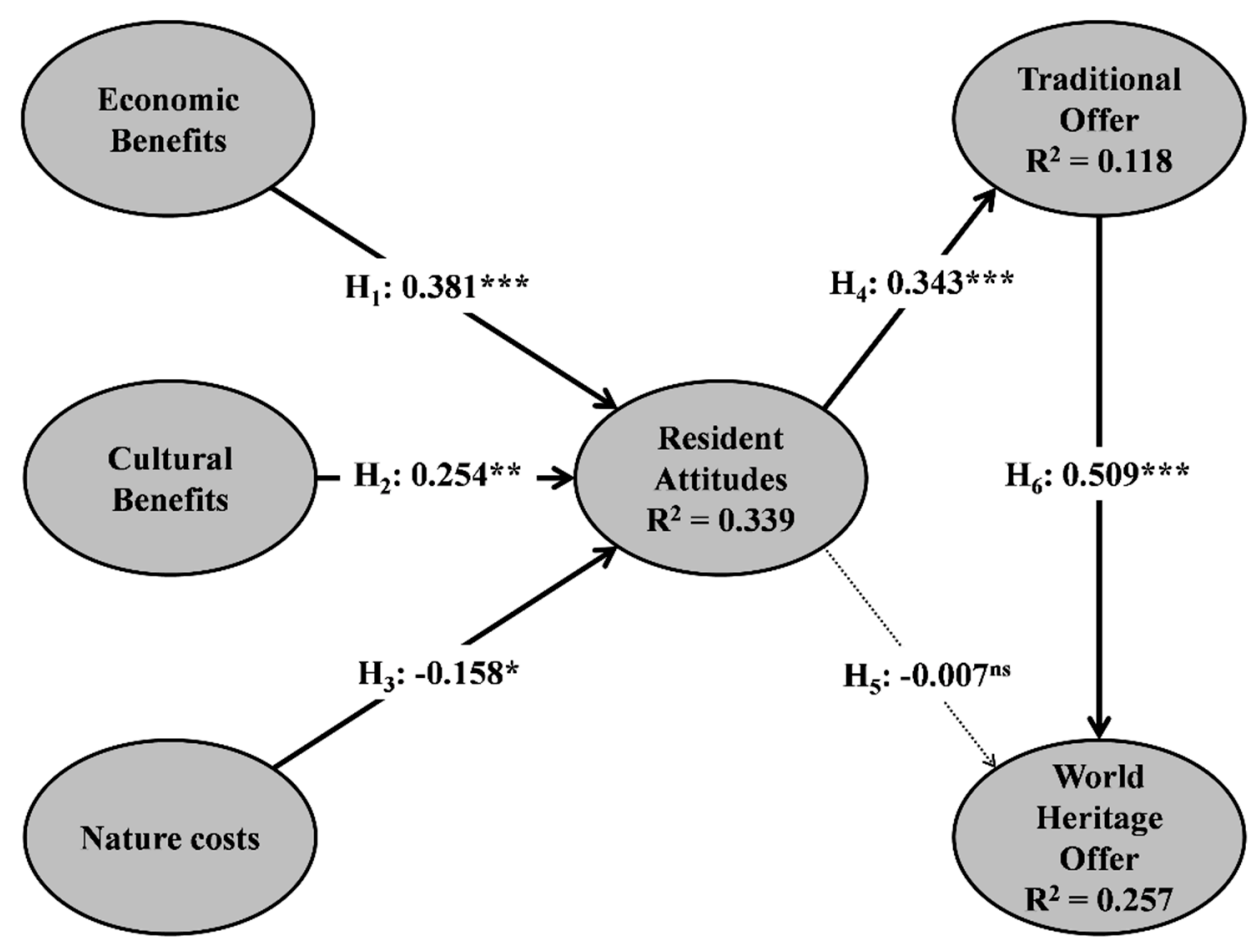

Figure 4. Result of the analysis of the SEM (own elaboration). * Significant at $0.1 ;{ }^{* *}$ significant at $0.01 ;{ }^{* * *}$ significant at $0.001 ;{ }^{\text {ns }}$ not significant.

\section{Critical Analysis of the WHS}

The oldest neighborhoods (Dalt Vila, Sa Penya and La Marina) had approximately 6000 inhabitants around 1900. In 2001, they had 1900 inhabitants [106], and in 2014, they had 2150 inhabitants. Over the last 20 years, this area has always represented approximately $5 \%$ of the municipality's population, with fluctuations due to the floating population. Social actions have been carried out, mainly in Sa Penya, although they have been insufficient for the problems of these neighborhoods; but there is no evidence of important projects to turn them into residential and commercial areas of reference, taking advantage of the emerging luxury tourism. Currently, this role is played by the Promenade, on the other side of the port $[12,15]$. An example of the actions to be taken is the historic center of Palma de Mallorca.

The musealization of the Renaissance walls and the improvement in lighting are possibly the most visible and important changes that have occurred. The musealization has allowed areas that are difficult to visit, such as the round walk between the bastion of Sant Bernat and the bastion of Sant Pere (Portal Nou), to be visited, and the entire walled enclosure to show quite exactly what it was in its heyday. However, even if the musealization achieves very spectacular remodeling, it will be necessary to carry out maintenance: some information stands are already deteriorated and illegible and need repairs; vegetation appears both on the walls and in some casemates and bastion, which gives the appearance of abandonment and damages the mortar (it is expensive but necessary to keep the walls clean); and there has been some vandalism (graffiti and missing objects).

In the WHS, there are two important museums: The Archaeological Museum of Ibiza and Formentera (MAEF) and the Museum of Contemporary Art of Ibiza (MACE). The Archaeological Museum has two locations: The Dalt Vila Archaeological Museum, created in 1907, and the Puig des Molins Monographic Museum, opened in 1968 and specialized in the Punic necropolis. In Spain, museums close very frequently for restorations and reforms, making visiting difficult [16], but in the case of the Archaeological Museum of Ibiza and Formentera, there are even fewer opportunities, since the Monographic Museum of Puig des Molins was closed for renovation between 1995 and 2013 and the Archaeological 
Museum of Dalt Vila has been closed since 2011. The Museum of Contemporary Art of Ibiza (MACE) was founded in 1969 and occupies the Weapons Room, the warehouses and the Powder magazine of the Renaissance walls. To these two museums must be added the Diocesan Museum (1965), the Puget Museum (2007), the Madina Yabisa Interpretation Center (2007) and the musealized casemates of Sant Pere (2007) and Sant Jaume (2008). The estimates of visits for 2008 were 24,000 (Dalt Vila Archaeological Museum), 20,000 (Contemporary Art Museum), 18,000 (Bastion of Sant Jaume), 13,000 (Madina Yabisa Interpretation Center), 11,000 (Bastion of Sant Pere), 10,000 (Puget Museum) and 10,000 (Diocesan Museum). The Puig des Molins Monographic Museum was closed [69]. If we take into account that many of these visits are by schoolchildren, and in that year, Ibiza received 2,094,000 tourists, this type of tourism has little relevance in the total count.

Among the events organized in relation to the WHS, Eivissa Medieval stands out, which is a medieval fair that combines handicraft markets and food products with performances and parades. Since 2001, it has been held on the second weekend in May and lasts for three days. Since 2005, it is estimated that it has had approximately 150,000 attendees. Other activities include events of various kinds in the bastion of Sant Pere during the summer; opera and classical music in the old town hall; and dramatized visits to Dalt Vila and the Puig des Molins necropolis [69]. Medieval fairs are very frequent and have a less than questionable level of historical rigor. Possibly, an improvement in the attendee numbers for these events would be achieved if they were spread out more, as some companies have discovered [107], and greater historical rigor may also help. Therefore, an option for improvement would be to organize craft markets and recreations of life in the modern age (time of the walls) throughout the spring and summer.

Some comments can be mentioned from the group World Heritage Cities of Spain. First of all, cities are not declared WHS; otherwise, elements of extraordinary global relevance, including buildings, historic town centers or parts of old towns, would not be the focuses. World Heritage Cities of Spain form a heterogeneous group, including historical centers of medieval origin (Ávila, Caceres, Cordoba, Cuenca, Salamanca, Santiago de Compostela, Segovia and Toledo) and historical centers predominantly of the modern age (Alcala, La Laguna, Ubeda and Baeza), but there are also cases in which the protected element is an archaeological site, specifically from Roman times (Mérida and Tarragona), or a mixed site that includes elements from different municipalities (Ibiza/Eivissa). These differences, together with their geographic dispersion, can limit the group's effectiveness in carrying out joint promotional actions. What stands out is the absence of Granada (Alhambra, Generalife and Albayzín, Granada, 1984) in the group, but this is possibly due to the fact that Granada's WHS have such national and international relevance that they do not need this type of collaboration. Proof of this is that the Alhambra is the most visited monument in Spain [24]. On the contrary, cities such as Ávila, Segovia and Salamanca have not yet positioned themselves in the international market [38].

Although some authors have considered that for cultural tourism, the ideal temperature is equal to or lower than $33^{\circ} \mathrm{C}[108,109]$, ideals for other activities allow proposing temperatures between 14 and $25^{\circ} \mathrm{C}$, with an optimum of $18-20^{\circ} \mathrm{C}[109,110]$. Taking the average data obtained at the Ibiza airport between 1981 and 2010 [111], we can see that the ideal months for cultural tourism are May and October, with April, June, September and November being very good (Figure 5). July and August suffer from high temperatures that make it difficult to walk during the day, making it necessary to focus on night events. December, January, February and March limit life on the street due to the cold weather, although temperatures are not as low as in other parts of Europe; therefore, it is advisable to prioritize daytime activities and in closed spaces—for example, shops, museums, bars and restaurants.

Although the best times for cultural tourism are spring and autumn, in the case of Ibiza's old town, the greatest tourist activity occurs during the summer (June to September) as a side product of the sun and beach tourism. On the one hand, there are excursions and itineraries throughout the walled enclosure, which last a few hours and are usually reserved 
for days not suitable for going to the beach. On the other hand, the Upper Town suburb and the La Marina neighborhood have important nightlife, which allows one to occupy one's time on the beach and at parties in the great nightclubs of the island. Therefore, there is no autonomous cultural tourism, but rather complementary tourism to the nightlife and wild excursions.

Even if it is promoted as a World Heritage City, "Ibiza, Biodiversity and Culture" is a mixed WHS (cultural and natural) located in various municipalities. It would not be a problem if there were no pro-city biases in investments, promotion and management. This bias between the inscribed sites is observed in the Ibiza World Heritage Site Consortium, attached to the Ibiza Town Hall. The result of this bias is that only small investments have been made in Sa Caleta, Ses Feixes and the Natural Park for a total of 2.2 million euros, compared to more than 25 million of the Consortium invested in Dalt Vila, the walled enclosure, Es Soto, La Marina, Sa Penya, Vara de Rey and the avenue España (this is outside of the WHS).

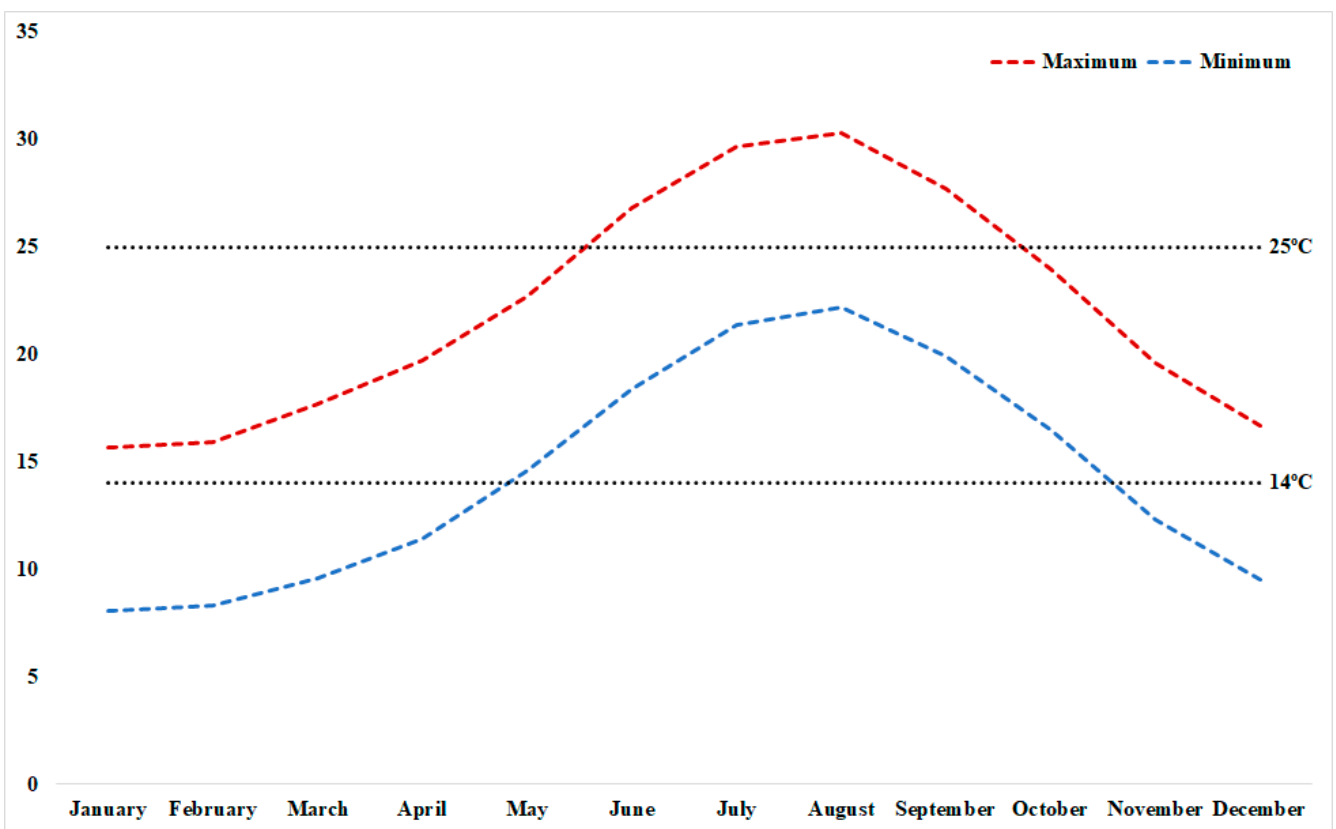

Figure 5. Average temperatures at Ibiza airport (own elaboration with public data [111]).

The oceanic Posidonia meadows are protected by the Ses Salines Natural Park, but the enormous maritime traffic in the area, especially in summer, is the main risk for the natural component of the WHS. The area between Ibiza and Formentera, known as Es Freus, has high boat traffic. In addition, in summer, there is a strong presence of pleasure boats that anchor in the area. Although buoys have been installed to allow anchoring without damaging the meadows, the small number and the fact that they do not allow lengths greater than $35 \mathrm{~m}$, which are very common today, does not solve the problem. Ses Illetes, the area near the port of La Savina and the island of S'Espalmador are the most problematic, due to the cases of anchoring that can damage the oceanic Posidonia meadows.

Ses Feixes work through a highly original irrigation system considered by some to be unique across the world and without a rival in other lake or marsh areas. This system takes advantage of potentially fertile lands and the abundance of fresh water in an almost superficial water table for a capillary irrigation system [64,65]. The Prat de Ses Monges could be partially recovered with great effort [65], but the city's high water consumption has greatly reduced the water table in the area, condemning this form of irrigation. In a visit to Prat de Ses Monges, five or six small plots were counted in a state qualifying as normal. 
The cultural landscape of Ses Salines is in a better state than Ses Feixes, since the productive activity is maintained. The survival of the activity is due to the quality of the extracted salt, mainly destined for export, and the actions of Salinera Española S.A. to modernize production procedures and offer high added value products, such as fleur de sel and sea salt crystals, focused on the gourmet market. However, the strong restrictions imposed on operations in the Natural Park limit the maintenance and improvement works for the ponds and ditches which are exploited.

Heritage and culture have an important component in politics in the Balearic Islands, could explain why the archipelago has, in the catalog of Goods of Cultural Interest of Spain, 3028 real estates of 16,146 total (18.75\%) and 991 movable properties of 45,206 total (2.19\%). The Balearic Islands are average in terms of movable property, but they are wealthy in real estate. Unfortunately, the declaration of an estate as a Good of Cultural Interest, or any other form of protection, is a very effective way to boycott projects of companies or opposing institutions. In addition, there is the custom of seeking great media and international repercussions in political discussions. For example, the works of Ibiza's port by the national government led protectionist organizations to carry out various actions that included sending reports to UNESCO. This information generated concern among the WHC, due to the possible indirect impacts on oceanic Posidonia, this being the reason for the 2009, 2010 and 2011 reports.

\section{Conclusions}

Ibizan residents clearly support nature and culture-based tourism, which are always seen as complementary to traditional sun and beach tourism. Therefore, the development of this type of tourism has the support of the population, but effective national and international promotion are lacking. For this reason, the declaration as a WHS by UNESCO can be very useful, even more so when it is known that it plays a vital role in building a competitive brand personality in tourism marketing [112].

In the case of Ibiza, the inscription of the mixed WHS of "Ibiza, Biodiversity and Culture" is an important but insufficient step for attracting culture and nature tourism. It is not enough to accompany the promotion of the inscribed elements with the WHS emblem; it is necessary to design attractive tourism offerings. The tourist products that can be offered are:

- Architectural Tourism, which has its main asset in the spectacular Renaissance walls, the main symbol of the city. However, the walls are complemented by the typical architecture of the old town neighborhoods, and outside the city, by the fortress churches and the traditional houses of the rural world. Common resources such as thematic and cultural routes [16] are limited on a little island, but these elements are the axis that allows offering urban itineraries or excursions of interest.

- $\quad$ The suburb of Dalt Vila and the La Marina and Vara de Rey neighborhoods-which have important gastronomic offerings, mainly on summer nights, although there are varied gastronomic offerings of all kinds throughout the island. Their novelty is to combine gastronomy with entertainment in approaches as diverse as Cabaret Lío on the Promenade, SubliMotion at the Hard Rock Hotel on Playa d'en Bossa and Heart at the Ibiza Gran Hotel on the Promenade. Perhaps the island should promote a gastronomic offer more differentiated and elegant than the current one in Dalt Vila, La Marina and Vara de Rey, one not going to the extremes of the examples indicated.

- Shopping tourism, which has an important tradition in the suburb of Dalt Vila and the La Marina and Vara de Rey neighborhoods with Adlib fashion. Adlib fashion emerged on the island in the 1970s, inspired by the styles of the hippie movement of that time [113]. There are also clothing stores not integrated into Adlib fashion and other various stores (leather, handicrafts, etc.). It should be a priority to diversify these shops, improve the store esthetics and facilitate collaboration in the tasks of preparation and marketing to allow greater survival of these SMEs. 
- The old town, which is also one of the most important areas for nightlife. Cocktail bars predominate in this area. The atmosphere of the nightlife venues is completed by the parades organized by the great nightclubs that promote parties every night. In addition, although the vast majority of the island's offer is gay-friendly, there is a leisure offer purely focused on gay tourism that is located on Virgin Street (Sa Penya neighborhood) in the suburb of Dalt Vila.

- Meetings, incentives, conventions and exhibitions (MICE) tourism. There is a growing pool of four and five-star hotels, both in the city and on the rest of the island, but only Santa Eulària des Riu Town Hall has taken action in this regard with the construction of a conference center. On the contrary, Ibiza Town Hall has not taken any action to promote this sector.

- $\quad$ Although the worldwide fame of Ibiza has led to fleeting mentions of the island in some international films (e.g., Quantum of Solace and Transporter 3 from 2008), no measures have been taken to encourage Ibiza and Formentera to be the setting for films with global impact. Ibiza has the potential to be the setting and context for large productions that convey to the public an admiration for it, as happens with the Bahamas; the Greek islands; and cities such as Venice, Paris, London, Hong Kong and New York-but without combined action and ambitions from the private and public sectors, this will not be feasible.

- The great marine wealth of the Natural Park of the Ibiza and Formentera salt flats, among which the inscribed oceanic Posidonia meadows stand out, offering enormous potential to organize underwater activities, linked to an ecotourism.

- Oceanic Posidonia meadows, which are a key element in the protection and formation of beaches, coastal dune structures and juniper forests. This coastal structure is common in the Natural Park, giving rise to some of the most touristy beaches. Specifically, Ses Illetes beach, in Formentera, is the most obvious case, since it exists thanks to the reefs of oceanic Posidonia. Ses Illetes is the most famous beach in Ibiza and Formentera, and one of the most famous in Spain and Europe, showing the importance of oceanic Posidonia meadows for sun and beach tourism.

- The cultural landscape of Ses Salines-which has the potential to provide a small amount of ornithological tourism, as it is an important enclave of migratory water birds and industrial tourism by showing the salt production process.

Since their inscription on the WHL, important restoration and musealization works have been carried out on inscribed sites, such as the walls or the Sa Caleta project, but some renovations have been controversial, as is the case for Can Botino. As in other locations in Spain $[16,114]$, there is still a lot of work to be done in terms of rehabilitating and conditioning the WHS and its surroundings, especially in the homes on Dalt Vila, Sa Penya and La Marina, and in the cultural landscape of Ses Feixes de Talamanca. Although they are in a better state of conservation, the archaeological sites, oceanic Posidonia meadows and salt flats have been forgotten in the investments, while uninscribed sites of the city have been improved with funds from the Consortium.

The management of local administrations in the restoration and enhancement of the inscribed sites can clearly be improved, as for other Spanish WHS [115]. Furthermore, investments have been more modest than elsewhere in Spain [49]. There have been improvements but also deficiencies in the coordination of administrations, and much remains to be done (maintenance of the walls and restored spaces, rehabilitation of historic neighborhoods, etc.) in a similar way to what occurs in other cities [39]. In the case of Ibiza, there is a certain confusion in the promotion regarding the elements included on the List, mainly in the buffer zone of the Upper Town. This confusion forced UNESCO to request, in 2017, clarification on the WHS limits, and in 2018, the government of Spain sent detailed maps of the inscribed sites and the buffer zones (currently available on the World Heritage Convention page).

Spanish cities with inscribed sites are characterized by the predominance of tourists and hikers having very short stays $[38,116]$, and a certain summer seasonality in less- 
developed destinations [116]. Only elements of great international relevance, such as the Alhambra in Granada, have managed to escape this limitation and have international and seasonally adjusted cultural tourism. Ibiza is little known as a cultural destination, but its image can make it an international cultural tourism provider, even if its sites do not have the relevance of the Alhambra, the Giza pyramids or the Taj Mahal.

Typical visits to inscribed sites on the UNESCO list are usually excursions, and in the best of cases, tourists stay for two days or so $[38,116]$. To achieve longer stays, it will be necessary to offer a range of products and activities that are as diversified as possible [116] from among the offerings mentioned above (architecture, gastronomy, shopping, nightlife, events, beaches, etc.). Ibiza has the advantage, compared to other locations, of great transport and accommodation infrastructure developed for sun and beach tourism, and a powerful international image that attracts tourists from all over the world. It is necessary to publicize the various types of cultural tourism offerings and encourage people to visit the island in spring and autumn. It is important to mention at this point that cultural tourism, which is still only emerging in the tourism sector, has great potential for sustaining traditional cultures [117], and each local community within a traditional culture is fundamental—even more so when UNESCO and the WHC have recognized it as a vital component of the sustainable management of heritage [118], which should be taken into account by the public administrators of tourism in Ibiza.

This paper is the first approach to the situation of the Ibiza WHS and its conversion into a tourist attraction. It has the limitations of being a case study and basing much of the analysis on secondary data. Future studies should deepen various aspects of this WHS and others in relation to management, conservation and tourism image.

Author Contributions: Conceptualization, D.D.P.-M. and J.R.-C.; methodology, J.R.-C.; validation, D.D.P.-M. and M.D.S.-F.; formal analysis, J.R.-C.; data curation, M.D.S.-F.; writing-original draft preparation, J.R.-C.; writing-review and editing, D.D.P.-M. and M.D.S.-F. All authors have read and agreed to the published version of the manuscript.

Funding: The APC was funded by the University of Magdalena, Colombia.

Institutional Review Board Statement: Not applicable.

Informed Consent Statement: Not applicable.

Data Availability Statement: The data presented in this study are available on request from the corresponding author.

Conflicts of Interest: The authors declare no conflict of interest.

\section{References}

1. Institut d'Estadística de les Illes Balears. Available online: http:/ /ibestat.caib.es/ (accessed on 15 June 2021).

2. Costa, A. La Triple Murada de l'Eivissa Àrab; Institut d'Estudis Eivissencs: Ibiza, Spain, 1985.

3. Costa, A. La Ciutat i Badia d'Eivissa; Editorial Mediterrània-Eivissa: Ibiza, Spain, 1996.

4. Cervera, L. El Triple Recinte de l'Eivissa Àrab; Editorial Mediterrània-Eivissa: Ibiza, Spain, 2001.

5. Cervera, L. Els Carrers de Dalt Vila; Editorial Mediterrània-Eivissa: Ibiza, Spain, 2002.

6. Cervera, L.; Marí, J. Els Carrers de l'Eivissa Antiga; La Caixa: Valencia, Spain, 1981.

7. Escandell, B. Aportación a la Historia de las Murallas Renacentistas de Ibiza; Institut d'Estudis Eivissencs: Ibiza, Spain, 1970.

8. Julbe, F. Eivissa Patrimoni de la Humanitat; Collegi Oficial d'Arquitectes de les Illes Balears: Ibiza, Spain, 2003.

9. Carbonero, M.A.; Puigròs, A.; Ribas, M.M. Diagnòstic Social d'Eivissa; Ajuntament d'Eivissa/Universitat de les Illes Balears: Palma de Mallorca, Spain, 2003.

10. Posadas, E.J. La Real Fuerza de Ibiza; Imprenta Ibosim: Ibiza, Spain, 1993.

11. Azpelicueta, M.C.; Ramón, J.; Abril, M. La oferta turística de la ciudad de Ibiza en el siglo XXI: Patrimonio de la Humanidad y establecimientos de lujo. HOLOS 2018, 34, 413-428. [CrossRef]

12. Peng, X.; Sánchez, M.D.; Ramón, J. The city of Ibiza's tourist offer in the 21st century. Tour. Plann. Des. 2018, 27, 84-99.

13. Ramón, J. Arte y artesanía en el imaginario y la oferta turística: El caso de Ibiza. Perip. Sust. 2020, 38, 150-173. [CrossRef]

14. Ramón, J.; Azpelicueta, M.C.; Serra, A. Ibiza, Biodiversidad y Cultura: Evolución y potencial turístico de un emplazamiento Patrimonio Mundial. Int. J. Sci. Manag. Tour. 2015, 1, 109-133. 
15. Ramón, J.; Peng, X.; Sánchez, M.D. Atractivos culturales para una diversificación del turismo en Ibiza. Tour. Hosp. Int. J. 2017, 8, 93-113.

16. Grande, J. Análisis de la oferta de turismo cultural en España. Estud. Tur. 2001, 150, 15-40.

17. Nuryanti, W. Heritage and postmodern tourism. Ann. Tour. Res. 1996, 23, 249-260. [CrossRef]

18. Castillo, J.I.; Castro, M.; López, L.; Zarzoso, Á. Assessing the tourism attractiveness of world heritage sites: The case of Spain. J. Cult. Herit. 2021, 48, 305-311. [CrossRef]

19. Cordente, M.; Esteban, A.; Mondéjar, J.A.; Andrés, M.E. Medición de motivaciones del turismo cultural en ciudades Patrimonio de la Humanidad. Rev. Anál. Tur. 2011, 12, 80-85.

20. González, F.; López, T. Culture, tourism and world heritage sites. Tour. Manag. Perspect. 2017, 24, 111-116. [CrossRef]

21. Jurado, C.; Sánchez, M. Willingness to pay for more sustainable tourism destinations in world heritage cities: The case of Caceres, Spain. Sustainability 2019, 11, 5880. [CrossRef]

22. Marrero, J.R.; Abdul-Jalbar, B. Turismo cultural y planificación del viaje: Un estudio de caso. Tour. Manag. Stud. 2012, 8, 41-47.

23. Martos, M. Las ciudades patrimoniales en el mercado turístico cultural. Úbeda y Baeza. Gran Tour Rev. Investig. Tur. 2012, 6, 63-82.

24. Melgosa, F.J. Cuarenta años de la convención del patrimonio mundial. In Proceedings of the XVII Congreso Internacional AECIT, O Carballiño, Spain, 21-23 November 2012.

25. Pérez, J.C.; Medina, M.J.; López, T.; Muñoz, G. Segmentación y percepción turística en destinos patrimonio material de la humanidad: Córdoba (España). Rev. Cienc. Soc. 2020, 26, 11-24. [CrossRef]

26. Pérez, J.C.; Medina, M.J.; Jara, C.; López, T. Segmentation of food market visitors in world heritage sites. case study of the city of Córdoba (Spain). Curr. Iss. Tour. 2021, 24, 1139-1153. [CrossRef]

27. Pulido, J.I.; Carrillo, I.; Mudarra, A.B. Factors that influence tourism expenditure in world heritage cities. Anatolia 2019, 30, 530-546. [CrossRef]

28. Pulido, J.I.; Carrillo, I.; Mudarra, A.B. Segmentation and characterization of tourists by spending composition in world heritage cities. J. Herit. Tour. 2021, 16, 230-245. [CrossRef]

29. Troitiño, M.A. El turismo cultural en las ciudades españolas Patrimonio de la Humanidad. In Turismo Cultural: El Patrimonio Histórico Como Fuente de Riqueza; Herrero, L.C., (Coord.); Fundación del Patrimonio Histórico de Castilla y León: Valladolid, Spain, 2000; pp. 111-138.

30. Valverde, J.; Gómez, G.; López, T.; Medina, M.J. Motivational analysis of tourists who visit a city with inscriptions world heritage site, Granada, Spain. Afr. J. Hosp. Tour. Leis. 2021, 10, 361-375. [CrossRef]

31. Castro, B.M.; Lois, R.C.; López, L. Historic city, tourism performance and development: The balance of social behaviours in the city of Santiago de Compostela (Spain). Tour. Hosp. Res. 2016, 16, 282-293. [CrossRef]

32. Gurrutxaga, M.; Porcal, M.C. Análisis de los retos de gestión del paisaje del Bien Pirineos-Monte Perdido tras dos décadas inscrito en la Lista del Patrimonio Mundial de UNESCO (1997-2018). Investig. Geogr. 2019, 71, 75-96. [CrossRef]

33. Larraz, B.; García, E. Depopulation of Toledo's historical centre in Spain? Challenge for local politics in world heritage cities. Cities 2020, 105, e102841. [CrossRef]

34. Morales, E.J.; Lanquar, R. El futuro turístico de una ciudad Patrimonio de la Humanidad: Córdoba 2031. Tour. Manag. Stud. 2014, 10, 7-16.

35. Parga, E.; Alonso, P. Sustainable tourism and social value at world heritage sites: Towards a conservation plan for Altamira, Spain. Ann. Tour. Res. 2019, 74, 68-80. [CrossRef]

36. Pino, J.M. The new holistic paradigm and the sustainability of historic cities in Spain: An approach based on the world heritage cities. Sustainability 2018, 10, 2301. [CrossRef]

37. Sánchez, J.M.; Rengifo, J.I.; Sánchez, M. Protected areas as a center of attraction for visits from world heritage cities: Extremadura (Spain). Land 2020, 9, 47. [CrossRef]

38. Troitiño, M.A.; Troitiño, L. Turismo y patrimonio en Castilla y León: Las ciudades Patrimonio de la Humanidad (Ávila, Salamanca y Segovia) como destinos turísticos de referencia. Polígonos Rev. Geogr. 2009, 19, 145-178. [CrossRef]

39. Troitiño, L. Las ciudades Patrimonio de la Humanidad de la región turística de Madrid: Niveles medio de funcionalidad y adecuación turística del patrimonio cultural. Pap. Tur. Pap. Tur. 2012, 51, 109-131.

40. Zárate, M.A. Estrategias y prácticas turísticas en una ciudad Patrimonio de la Humanidad, Toledo. Geographicalia 2007, 51, 81-106. [CrossRef]

41. Mayol, G.; Melis, L.; Serra, S. El turismo cultural a dos espais declarats Patrimoni de la Humanitat: Els casos d'Eivissa i Formentera i de la Serra de Tramuntana de Mallorca. In Proceedings of the 2n Congrés Oci i Turisme (OCITUR 2014), Maresme, Spain, 29 June-2 July 2014.

42. UNESCO. World Heritage List. World Heritage Convention (UNESCO) 2021. Available online: http://whc.unesco.org/ (accessed on 15 June 2021).

43. Morales, J. Demande d'Inscription sur la Liste du Patrimoine de l'Humanite des Biens Culturels et Naturels de l'Ile d'Ibiza: Biodiversite el Culture; Tome I: Introduction Generale; Biens Culturels (Premiere Parte); Mairie d'Ibiza, Conseil Insuler d'Ibiza et Formentera, Gouvernement Balear, Mairie de San Jose et Mairie de Formentera: Balearic Islands, Spain, 1998.

44. Antón, C.; Camarero, C.; Laguna, M. Towards a new approach of destination loyalty drivers: Satisfaction, visit intensity and tourist motivations. Curr. Issues Tour. 2017, 20, 238-260. [CrossRef] 
45. Ortiz, P.; Antunez, V.; Martín, J.M.; Ortiz, R.; Vázquez, M.A.; Galán, E. Approach to environmental risk analysis for the main monuments in a historical city. J. Cult. Herit. 2014, 15, 432-440. [CrossRef]

46. García, M.; de La Calle, M. Capacidad de carga en grandes recursos turístico-culturales. An. Geogr. Univ. Complut. 2012, 32, 253-274. [CrossRef]

47. Jiménez, M.; Domínguez, M.J.; Aranburu, A.; Martos, E. Quantitative indexes based on geomorphologic features: A tool for evaluating human impact on natural and cultural heritage in caves. J. Cult. Herit. 2011, 12, 270-278. [CrossRef]

48. Mondéjar, J.; Vargas, M. Construcción de un modelo para el análisis de motivaciones sobre la elección de un destino turístico. Estud. Perspect. Tur. 2009, 18, 400-413.

49. García, M. Entidades de planificación y gestión turística a escala local. El caso de las ciudades Patrimonio de la Humanidad de España. Cuad. Tur. 2007, 20, 79-102.

50. Lara, F.; López, T.J. El turismo como motor de desarrollo económico en ciudades Patrimonio de la Humanidad. Pasos Rev. Tur. Patrim. Cult. 2004, 2, 243-256. [CrossRef]

51. Medina, J.C.; de Pablos, J.C. Metamorfosis del Albaicín (Granada): Del aislamiento a la interdependencia. Cuad. Geogr. 2002, 32, 73-96. [CrossRef]

52. Viu, J.M.; Fernández, J.R.; Caralt, J.S. The impact of heritage tourism on an urban economy: The case of Granada and the Alhambra. Tour. Econ. 2008, 14, 361-376. [CrossRef]

53. Palau, R.; Forgas, S.; Sánchez, J.; Prats, L. Tourist behavior intentions and the moderator effect of knowledge of UNESCO world heritage sites: The case of La Sagrada Família. J. Travel Res. 2013, 52, 364-376. [CrossRef]

54. Monteiro, L.D. The Mezquita of Córdoba is made of more than bricks: Towards a broader definition of the "heritage" protected at UNESCO world heritage sites. Archaeologies 2011, 7, 312-328. [CrossRef]

55. Morales, J. Demande d'Inscription sur la Liste du Patrimoine de l'Humanite des Biens Culturels et Naturels de l'Ile d'Ibiza: Biodiversite el Culture; Tome II: Biens Culturels (Seconde Parte); Mairie d'Ibiza, Conseil Insuler d'Ibiza et Formentera, Gouvernement Balear, Mairie de San Jose et Mairie de Formentera: Balearic Islands, Spain, 1998.

56. Silvestre, M.D. Demande d'Inscription sur la Liste du Patrimoine de l'Humanite des Biens Culturels et Naturels de l'Ile d'Ibiza: Biodiversite el Culture; Tome III: Biens Naturels; Mairie d'Ibiza, Conseil Insuler d'Ibiza et Formentera, Gouvernement Balear, Mairie de San Jose et Mairie de Formentera: Balearic Islands, Spain, 1998.

57. Tur, A. Murades. In Enciclopèdia d'Eivissa i Formentera; Cirer, F., Dir.; Consell Insular d'Eivissa i Formentera: Ibiza, Spain, 2004; Volume VIII.

58. Prats, J.A. Calvi, Gianbattista. In Enciclopèdia d'Eivissa i Formentera; Cirer, F., Dir.; Consell Insular d'Eivissa i Formentera: Ibiza, Spain, 1996; Volume II.

59. Ferrer, A. Palearo, Giovan Giacomo -el Fratín-. In Enciclopèdia d'Eivissa i Formentera; Cirer, F., Dir.; Consell Insular d'Eivissa i Formentera: Ibiza, Spain, 2006; Volume IX.

60. Vallès, R. Dalt Vila. In Enciclopèdia d'Eivissa i Formentera; Cirer, F., Dir.; Consell Insular d'Eivissa i Formentera: Ibiza, Spain, 2000; Volume IV.

61. Vallès, R. Penya, Sa. In Enciclopèdia d'Eivissa i Formentera; Cirer, F., Dir.; Consell Insular d'Eivissa i Formentera: Ibiza, Spain, 2006; Volume IX.

62. Cuesta, M. Marina, La. In Enciclopèdia d'Eivissa i Formentera; Cirer, F., Dir.; Consell Insular d'Eivissa i Formentera: Ibiza, Spain, 2004; Volume VIII.

63. Planells, J. Feixa. In Enciclopèdia d'Eivissa i Formentera; Cirer, F., Dir.; Consell Insular d'Eivissa i Formentera: Ibiza, Spain, 2001; Volume V.

64. Foster, G.M. Las “Feixes” de Ibiza. Estud. Geogr. 1952, 13, 559-568.

65. Vallès, R. Feixes, Ses. In Enciclopèdia d'Eivissa i Formentera; Cirer, F., Dir.; Consell Insular d'Eivissa i Formentera: Ibiza, Spain, 2001; Volume V.

66. Ramon, J. Caleta, Sa. In Enciclopèdia d'Eivissa i Formentera; Cirer, F., Dir.; Consell Insular d'Eivissa i Formentera: Ibiza, Spain, 1996; Volume II.

67. Ramón, M. La Posidònia a les Pitiüses. El Tresor del Mediterrani; Institut d’Estudis Eivissencs: Ibiza, Spian, 2007.

68. Vallès, R. Salines, Ses. In Enciclopèdia d'Eivissa i Formentera; Cirer, F., Dir.; Consell Insular d'Eivissa i Formentera: Ibiza, Spain, 2011; Volume XI.

69. Gurrea, R.; Herrera, M. 10 Anys Eivissa Patrimoni de la Humanitat 1999-2009; Ajuntament d'Eivissa: Ibiza, Spain, 2009.

70. Ciudades Patrimonio de la Humanidad de España. Presentación del Grupo. Available online: http:/ / www.ciudadespatrimonio, org / (accessed on 15 June 2021).

71. Mondéjar, J.A.; García, M.C.; Mínguez, R.; Mondéjar, J.; Cordente, M. Cultural tourism, using a multicriteria analysis: Spanish world heritage cities. Int. J. Manag. Inform. Syst. 2010, 14, 35-44. [CrossRef]

72. Gursoy, D.; Jurowski, C.; Uysal, M. Resident attitudes: A structural Modeling Approach. Ann. Tour. Res. 2002, 29, 79-105. [CrossRef]

73. Ringle, C.M.; Wende, S.; Will, S. SmartPLS 2.0 (Beta); SmartPLS: Hamburg, Germany, 2005.

74. Henseler, J.; Ringle, C.M.; Sinkovics, R.R. The use of Partial Least Squares Path Modeling in international marketing. In Advances in International Marketing; Sinkovics, R.R., Ghauri, P.N., Eds.; Emerald: Bingley, UK, 2009; pp. 277-320. 
75. Ramón, J.; Álvarez, D.; Sánchez, M.D. Principales causantes de la actitud de los residentes: Comparativa entre dos destinos de playa. Rev. Port. Estud. Reg. 2018, 47, 37-48.

76. Sánchez, M.D.; Ramón, J. The perception of the effect of tourism on the local community before the Ibiza Smart Island Project. In Handbook of Research on Entrepreneurial Development and Innovation within Smart Cities; Carvalho, L.C., Ed.; IGI Global: Hershey, PA, USA, 2017; pp. 392-416.

77. Teye, V.; Sirakaya, E.; Sönmez, S.F. Resident's attitudes toward tourism development. Ann. Tour. Res. 2002, 29, 668-688. [CrossRef]

78. Ap, J.; Crompton, J.L. Developing and testing a tourism impact scale. J. Travel Res. 1998, 37, 120-130. [CrossRef]

79. de Freitas, I.V.; Sousa, C.; Ramazanova, M. Historical landscape monitoring through residents' perceptions for tourism: The world heritage Porto city. Tour. Plan. Dev. 2021, 18, 294-313. [CrossRef]

80. Gee, C.Y.; Mackens, J.C.; Choy, D.J. The Travel Industry; Van Nostrand Reinhold: New York, NY, USA, 1989.

81. McIntosh, R.W.; Goeldner, C.R. Tourism Principles, Practices, Philosophies; Wiley: New York, NY, USA, 1990.

82. Ramón, J.; Álvarez, D.; Sánchez, M.D. Residents' attitudes towards different tourist offers: Maldonado-Punta del Este conurbation (Uruguay). Eur. J. Gov. Econ. 2019, 8, 30-47. [CrossRef]

83. Ramón, J.; Álvarez, D.; Sánchez, M.D. Gestión del destino turístico: Percepción de los impactos sostenibles. Rev. Port. Estud. Reg. 2020, 53, 7-21.

84. Jurowski, C.; Uysal, M.; Williams, R.D. A theoretical analysis of host community resident reactions to tourism. J. Travel Res. 1997, 36, 3-11. [CrossRef]

85. Ramón, J. Efecto de la economía y el entorno en los residentes. PASOS Rev. Tur. Patrim. Cult. 2015, 13, 1371-1386. [CrossRef]

86. Sánchez, M.D.; Ramón, J. Impacto de las actitudes de los residentes sobre el grado de aceptación del turismo de playa, el turismo de deportes, el turismo de naturaleza y el turismo cultural. Podium Sport Leis. Tour. Rev. 2016, 5, 56-75. [CrossRef]

87. Sánchez, M.D.; Álvarez, D.; Ramón, J. The impact of residents' posture on the degree of acceptance of sports tourism in comparison to other tourist offers in Punta del Este. In Sports Management as an Emerging Economic Activity: Trends and Best Practices; Peris, M., Álvarez, J., Del Río, M.C., Eds.; Springer: Berlin/Heidelberg, Germany, 2017; pp. 39-56.

88. Ayres, R. Tourism as a passport to development in small states: Reflections on Cyprus. Int. J. Soc. Econ. 2000, 27, 114-133. [CrossRef]

89. Perdue, R.R.; Long, P.T.; Kang, Y.S. Resident support for gambling as a tourism development strategy. J. Travel Res. 1995, 34, 3-11. [CrossRef]

90. Besculides, A.; Lee, M.; McCormick, P. Resident's perceptions of the cultural benefits of tourism. Ann. Tour. Res. 2002, 29, 303-319. [CrossRef]

91. Ap, J. Residents' perceptions on tourism impacts. Ann. Tour. Res. 1992, 19, 665-690. [CrossRef]

92. Lawson, R.W.; Williams, J.; Young, T.; Cossens, J. A comparison of residents attitudes towards tourism in 10 New Zealand destinations. Tour. Manag. 1998, 19, 247-256. [CrossRef]

93. Johnson, J.D.; Snepenger, D.J.; Akis, S. Residents' perceptions of tourism development. Ann. Tour. Res. 1994, 21, 629-642 [CrossRef]

94. Sánchez, M.D.; Álvarez, D.; Ramón, J. Difficulties for enjoyment of public spaces by residents: Maldonado-Punta del Este conurbation. Int. J. Tour. Cit. 2018, 4, 391-407. [CrossRef]

95. Newby, H. Green and Pleasant Land? Social Change in Rural England; Wildwood House: London, UK, 1979.

96. Jurowski, C.; Uysal, M.; Williams, R.D.; Noe, F.P. An examination of preferences and evaluations of visitors based on environmental attitudes: Biscayne Bay National Park. J. Sustain. Tour. 1995, 3, 73-86. [CrossRef]

97. Uysal, M.; Jurowski, C.; Noe, F.P.; McDonald, C.D. Environmental attitude by trip and visitor characteristics: US Virgins Islands National Park. Tour. Manag. 1994, 15, 284-294. [CrossRef]

98. Carmines, E.; Zeller, R. Reliability and Validity Assessment, N. 07-017; Sage University Paper Series on Quantitative Applications in the Social Sciences; Sage: Beverly Hills, CA, USA, 1979.

99. Cronbach, L.J. Essentials of Psychological Testing, 3rd ed.; Harper \& Row: New York, NY, USA, 1970.

100. Werts, C.E.; Linn, R.L.; Jöreskog, K.G. Interclass reliability estimates: Testing structural assumptions. Educ. Psychol. Meas. 1974, 34, 25-33. [CrossRef]

101. Anderson, J.C.; Gerbing, D.W. Structural equation modeling in practice: A review and recommended two-step approach. Psy. Bull. 1988, 103, 411-423. [CrossRef]

102. Bagozzi, R.P.; Yi, Y. On the evaluation of structural equation models. J. Acad. Mark. Sci. 1988, 16, 74-94. [CrossRef]

103. Chin, W.W. Issues and opinions on structural equation modeling. MIS Q. 1998, 22, 7-16.

104. Davison, A.; Hinkley, D. Bootstrap Methods and Their Application; Cambridge University Press: Cambridge, UK, 1997.

105. Hair, J.; Hult, G.; Ringle, C.; Sarstedt, M. A Primer on Partial Least Squares Structural Equation Modeling (PLS-SEM); Sage: Thousand Oaks, CA, USA, 2014.

106. Julbe, F.; Pascuet, R. Introducción al Análisis Histórico de la Ciudad de Ibiza (De la Ciudad Púnica a 1912); Col·legi Oficial d'Arquitectes de les Illes Balears: Ibiza, Spain, 2001.

107. Fernández, S.; Ramón, J. Los eventos como estrategia de diferenciación: El caso de fun \& music de la compañía naviera Baleària. Rev. Ib. Tur. (RITUR) 2014, 4, 88-112.

108. Besancenot, J.P. Clima y Turismo; Editorial Masson: Barcelona, Spain, 1991. 
109. Coll, M.A.; Seguí, M. El papel del clima en la estacionalidad turística y la configuración de productos turísticos emergentes. El caso de Mallorca. Cuad. Tur. 2014, 33, 15-30.

110. Navarrete, R. Factores influyentes para la práctica segura de la educación física. Rev. Dig. Efdep. 2010, 14 , e141.

111. AEMET. Datos Climatológicos: Valores Normales. Agencia Estatal de Meteorología. Available online: http://www.aemet.es/ (accessed on 15 June 2021).

112. Hassan, M.A.E.; Zerva, K.; Aulet, S. Brand Personality Traits of World Heritage Sites: Text Mining Approach. Sustainability 2021, 13, 6142. [CrossRef]

113. Ramón, J. Moda Adlib: De los hippies a los turistas. Int. J. Sci. Manag. Tour. 2016, 2, 177-206.

114. Troitiño, M.A. Ciudades históricas, turismo y desarrollo sostenible. In Ciudades Históricas: Conservación y Desarrollo; Castillo, M.A., Ed.; Fundación Argentaría: Madrid, Spain, 2000; pp. 67-96.

115. Pardellas, X.X.; Padín, C. El camino de Santiago portugués en Galicia y las estrategias turísticas locales. Rev. Anal. Tur. 2014, $17,51-59$.

116. Almeida, F. Análisis de la Estructura turística de las ciudades Patrimonio de la Humanidad de España. Baética Estud. Arte Geogr. Hist. 2007, 29, 57-72. [CrossRef]

117. Lai, S.; Zhang, S.; Zhang, L.; Tseng, H.-W.; Shiau, Y.-C. Study on the Influence of Cultural Contact and Tourism Memory on the Intention to Revisit: A Case Study of Cultural and Creative Districts. Sustainability 2021, 13, 2416. [CrossRef]

118. Jang, H.; Mennis, J. The Role of Local Communities and Well-Being in UNESCO World Heritage Site Conservation: An Analysis of the Operational Guidelines 1994-2019. Sustainability 2021, 13, 7144. [CrossRef] 